\title{
地方中心都市における転居を通じた都市コンパクト化による自動車依存低減の可能性*
}

\section{The Possibility for Reduction of Car Dependence from the Perspective of Relocation for Compact City in Central City of Local City*}

中道久美子 $* *$ ・谷口守*** ・ 松中亮治 $* * * *$

\author{
By Kumiko NAKAMICHI** • Mamoru TANIGUCHI*** $\cdot$ Ryoji MATSUNAKA****
}

\section{1.はじめに}

近年、サステイナビリティを実現する都市構造として コンパクトシティが注目され、その「人口密度が高い都 市ほど交通環境負荷が低減される」という分かりやすい 図式1により、様々な行政主体でその推進が表明されて いる。最近では国土交通省の社会資本整備審議会答申に おいて「集約型都市構造」として都市コンパクト化政策の 重要性が明記されるに至っており2)、これを受けて地 方・自治体レベルでも導入の試みが増加している。この ような動きに対応した最近の研究としては、都市コンパ クト化に対し環境負荷の視点を含めた経済評価を行った 研究3)や、アクセシビリティに着目した研究4)，計画手法 や空間構成についてまとめたもの等が挙げられる。

しかし、実際に都市コンパクト化を実現するには、長 期的な視点から郊外から都心部等への居住者の転居を促 進していく必要がある。その一方で、例えば郊外で自動 車に非常に依存した生活をしていた居住者が都心や駅の 近くへの転居を行ったとしても、その居住者が自動車に 依存した生活を単純に放棄するとは限らない可能性があ り、都市コンパクト化により交通環境負荷を低減させる ためには、転居が起こるとともにその前後で居住者の交 通行動が変化し自動車依存状況が改善される必要がある。 コンパクトシティと居住誘導に関しては、住宅需要マネ ジメントに関する論説(6)を始めとして、経済的要素も考 慮した転居誘導施策による住夕替え促進効果に関する分 析7)、さらには住宅供給や交通施設整備のような具体的 な事業を想定した研究8),9 も見られる。最近では都市構 造と転居との関連について分析した研究 ${ }^{10)}$ 、最近の都 心マンション建設による短期的な影響に関する研究11)

*キーワーズ : 都市婳、地区計画 住宅立地 コンパクトシティ **学生員、環修、岡山大学大学院環境学研究科

(岡山市津島中3-1-1 dev18101@cc.okayam-u.ac.jp)

***正員、工博、岡山大学大学院環境学研究科 (岡山市津島中3-1-1 Tel.Fax.086-251-8850)

***正員、博 (工) 、京都大学大学院工学研究科 (京都市西京区京都大学桂 matsu@urban.kuciv.kyoto-u.ac.jp)
TODといら視点から住み替えのインセンティブと居住 地選択のマネジメントに言及した研究 ${ }^{12}$ もある。また、 郊外居住者の抱くまちなか居住のイメージと実際のまち なか居住者の意識との乘離や郊外居住者のまちなか居住 意向について分析した研究 ${ }^{13}$ や、交通環境負荷指標に対 する主要な変数は人口密度だけではなく個人・世帯の属 性も関連しているというSelf selection biasの問題を指摘 した研究 ${ }^{14), 15)}$ も行われつつあり、特定都市や特定事業を 対象とした研究では多くの蓄積がある。また、転居と交 通行動変化に関する研究としては、居住地が交通行動に 及ぼす影響を分析した基礎的な研究16),17)を始めとして、 大都市郊外住宅団地を対象に時間経過に伴う生活様式の 変化と移動との関連性について分析することで居住者属 性の変化に基づく移動ニーズ（交通利用）を予測した研 究18)や、シナリオ分析により都心部への転居促進だけで は交通環境負荷の改善は望めず抜本的な行動变容の促進 の必要性があることを示唆した研究19)が挙げられる。さ らに、地区属性・個人属性と交通環境負荷との関連の実 態分析を行うことで居住者が郊外から都心に転居しても 自動車への依存状況には影響がなく交通環境負荷は改善 されない可能性があることを示唆した先行研究20)や、実 データから大都市圈を対象に地区属性別に転居前後の交 通行動変化の実態を明らかにした先行研究 ${ }^{21)}$ があり、具 体的に転居前後の交通行動と居住地選択行動の関係を分 析した研究22),23)も行われている。しかし、特定都市もし くは特定地区での転居を対象とした研究が多く、特に都 市の低密化とそれによる交通環境負荷の増大が問題視さ れている地方圈の都市において、転居前の居住地と転居 後の居住地において実際に交通行動が変化したのかとい うことは世帯属性も含む一般性が確保されたデータを用 いて十分に明らかにされていない。

そこで本研究では、地方圈の都市の中でも、都心の 中心市街地から農村的要素も有寸る低密な郊外まで、幅 広い住宅地タイプを含む地方中心都市に着目し、一般性 を確保できる全国規模のデータを用い、転居前後の交通 行動の変化についてその実態を地区属性別に明らかにす ることを目的とする。ここで地方中心都市(Central City in Local Area, CL)とは、三大都市圏以外の都市で、県 
庁所在地または人口 15 万人以上の都市とする。そして具 体的には地区属性によって住宅地を分類し、そのタイプ ごとに分析を行い、どのような住宅地で交通機関、特に 自動車の利用が増加もしくは減少しているのか明らかに する。さらに、過去に転居してきた人が現在までに自動 車利用頻度が変化していることに配慮した考察が行える よう転居してきた時期についても考慮し、居住者の特性 を把握するために都心からの距離や転居前後での住宅の 種類や建て方の変化についても把握しながら、自動車利 用頻度の変化について分析を行う。以上より、郊外から 撤退し交通等のインフラ整備の整った都心あるいは駅周 辺部に人口を誘導するようなコンパクトシティの推進に よって、交通環境負荷を低減させる可能性があるか考察 する。なお、転居のきっかけとしては離家あるいは結 婚・子どもの誕生や、所得、普段使用寸る買い物施設や 勤務地等、世帯に関わる指標も影響していると考えられ るが、本研究では、そもそも転居を対象にした地区レべ ルの分析が行われていないということに着目し、地区ご とにマクロな傾向を把握することを目的とする。

\section{2. 本研究の特長}

1）転居前後の情報が一貫して十分に確保されたデータ を用い、実際の交通行動変化を初めて明らかにした。

2）地方中心都市の住区を網羅した膨大な蓄積データを 活用することで、転居前後の交通行動を数多くの住 宅地タイプ間で横並びに比較・考察できた。

3）近年顕著な都心マンション建設に伴う転居行動のみ を対象とした瞬間風速的な分析ではなく、通常は把 握し難い昔の転居を含めた過去の長期間に亘る転居 を全て対象とした、累積的視点に基づく分析である。

4) これまでの転居を全てプールさせた分析だけでなく 転居してきた時期にも着目して分析を行っており、 近年の動向を知ることができる。

5) 都心部か郊外部かといったことだけでなく住宅の種 類・建て方や入居時期にも着目しているため、居住 者のライフステージと絡めた考察を行うことができ る。

なお、本研究では住宅地タイプ、入居時期、住宅の 種類及び建て方が全て交通行動に影響しているという仮 説の基に研究を行うものとする。そして、住宅地を分類 してそのタイプごとの特性を見ながら転居前後の交通行 動変化について分析することで、これらの諸変数の組み 合わせについて考察することとする。

\section{3. 使用データと分析内容}

本研究では、全国に通じる一般的な分析結果を得る
ため、全国都市パーソントリップ調査（以下全国PT調 查）のデータを用いて住区の基本的な特性から住区を類 型化した住宅地タイプ24)を使用する。この全国PT調査は 人口規模の異なる性格が多様な都市を完全にカバーする ように設計されており、さらにその中で各都市から住民 基本台帳を基に約30の地区（合計300世帯を満たす町丁 目レベル) をランダムサンプリングしているため、調査 区画の選定方法に偏りがないことが保証されている。全 国PT調查の調查区画面積の中央值は29.3haであり、一般 的な個別の住宅地開発プロジェクトの規模（数haから10 Oha）にほぼ相当する。本研究では、個人調査サンプル と住宅地の対応が十分な精度で可能な21都市の551調查 住区に及ぶデータを住宅地タイプ設定の際の分析対象と した。詳しい設定方法については省略するが、住区を類 型化していくにあたって、都市計画事業・政策を実施す る上でコントロール可能な項目を採用することを基本思 想として住区特性と居住者の自動車然料消費量との相関 関連を分析したところ、人口密度の他、最寄り駅からの 距離のような鉄道サービスに関する項目で自動車燃料消 費量との関連性が見られた。さらに土地利用・建物立地 をコントロールする要素として政策検討の際には実際の 土地利用実態よりも重要である土地利用規制に関する指 標も加え、分類条件を設定した。そして十分な分析精度 が保障できる程度のサンプル数（300～500）を確保する ことを考慮しながら類似した特性をもつ住区をまとめて いき、最終的にCL1 CL40という40種類の住宅地タイプ を設定した。なお、交通環境負荷の違いを把握しやすい よう住宅地タイプ番号はCL1, CL2, CL3，ㄴと1人1日自 動車燃料消費量が大きい順に設定した。

また、転居に関するデータについては、特に平成17 年全国PT調査の意識調査票Bにおける調查結果を利用す る。この調査では、年または月または週あたりの各交通 機関の利用頻度が利用日数で質問されている。そしてそ の利用頻度について、「（現在の居住地の前にお住まい の場所では、）以下の交通機関をどのくらい利用してい ますか/していましたか」という設問により、平成17年 の調査時点の状況とともに、過去の居住地における状況 についても同様に調査されている。これは、転居経験を 長期間に亘って把握することを念頭に置いた調査である ためパネル調査や転居時ごとに行うダイアリー調査のよ うな詳細な調査ではなく、特に転居前については過去の 時点を特定した調査ではない。しかし、それぞれの交通 機関について年または月または週あたりという利用頻度 の規模を選択肢として与えた上で、その規模別に利用日 数を尋ねることで、転居前後でおおよその值として大き な変化があるかということを比較できるように配慮され ている。そして、そのような理由から転居直前と転居直 後の明確な利用頻度を問うのではなく、以前に居住して 
いた場所あるいは現在の居住地では概してどの程度各交 通機関を利用していたかを質問している。そのため、特 に転居後については転居時の交通行動変化と転居後から 現在までの交通行動変化とが混在していることとなるた め、後の分析では日本全体の自動車依存状況の変化につ いて勘案した考察を行うこととする。本研究では、この 調查項目における結果を年間日数に換算した值を用い、 各交通機関利用頻度の変化を比較するとともに、転居経 験、転居予定の調查項目についても分析を行った。

\section{4. 住宅地タイプ別の交通機関利用頻度変化分析}

住宅地タイプ別に転居前後の各交通機関利用頻度変 化を分析した結果、全体としては自動車利用頻度が増加 した住区数が地方中心都市全体の住区数の $90.2 \%$ 占め ており、同割合が大都市圈中心都市では46.4\%、大都市 圈衛星都市では75.9\%、そして地方都市でも $88.6 \%$ 、゙あ ったのに対し、地方中心都市では他の都市タイプと比較 しても自動車利用頻度が増加した住区が圧倒的に多いこ とが明らかになった。ここで転居は世帯単位で行われる ことが多いため世帯数で捉えることも重要であるが、本 研究では都市内の住宅地ごとの傾向を捉えることを趣旨 としているため、ここでは住区数で比較している。ここ では紙数の都合上、結果の一部を、各住宅地タイプの分 類条件、転居経験の有無及び転居予定の項目の結果、さ らに該当する住区の概要として自動車燃料消費量や人口、 人口密度等の平均值、さらに各交通機関利用頻度の転居 前後の值を比較した検定の結果とともに図一1に示寸。 これらは分析の結果、特に自動車の利用頻度の増減の変 化幅が大きいものを抜き出しており、都市圈の中での位 置とイメージが分かりや寸いよう都心からの距離の平均 值が近い順に並心゙、その住宅地タイプの特徽を表す典型 的な画像とともに示している。以下に考察を示す。

1) まず、住宅地タイプCL13やCL15のように市街化調 整区域の割合が高い郊外部の住宅地タイプにおいて 自動車利用頻度が増加していることを実データから 確認することができた。これらは人口密度区分が50 人ha未満と非常に小さく、その平均值を見ても住宅 地タイプCL13で31.1人/ha、住宅地タイプCL15で20.8 人/haと、他の住宅地タイプと比較しても小さな值と なっていることが分かる。

2) その他に自動車の利用頻度の増加が目立つのは住宅 地タイプCL34、CL6、CL8のような都心周辺部から 郊外部の間に位置する住宅地タイプである。これら はいずれも低層住居専用地域や住居地域の割合が高 い住宅地タイプで、人口密度も小さいことが分かる。 3) 一方で、同じように都心周辺部から郊外部の間に位 置する住宅地タイプでも、人口密度が100人/ha以上
と高密で住居地域の割合が高い住宅地タイプCL27や、 人口密度は 50 人ha未満と小さいが中高層住居専用地 域の割合が高く、図中の画像を見ても一定地域に高 密に居住している傾向が大きい住宅地タイプCL21で は、自動車利用頻度が減少している。そして住宅地 タイプCL21では自動車利用頻度が減少する代わりに わずかながらではあるが路線バスの利用頻度が増加 しており、また住宅地タイプCL27では自転車や徒歩 の利用頻度が増加している。その半面、どちらの住 宅地タイプでも自動車の利用頻度の減少は有意差が 認められるほどのものではなく、さらに鉄道の利用 頻度は減少していることが分かる。

4) 住宅地タイプCL37は都心からも駅からも近い都心部 の住宅地タイプであるが、このように本来なら自動 車を利用しなくても利便性の高い住宅地に住んでい る人でも、自動車の利用頻度が増加してしまってい ることが分かる。

5)さらに、住宅地タイプCL24は商業系の用途地域と住 宅系の用途地域を混合させたミクスト・ユースの住 宅地タイプであり、都心から都心周辺部の住宅地に あたるが、ここでも自動車利用頻度は有意差が認め られるほど増加しており、その増加幅は先述の住宅 地タイプCL37よりもさらに大きい。

6）地方中心都市では、住宅地タイプCL37の他、住宅地 タイプCL6、CL8、CL13のように駅からの距離が1k $\mathrm{m}$ 未満と鉄道の利便性が高いはずの住宅地タイプで も自動車利用頻度の増加が顕著であり、鉄道の利便 性の大小に関わらず地方中心都市全体として自動車 依存の傾向が強まっていることが分かる。さらにそ れ以外の住宅地タイプを含めて見ても住宅地タイプ CL13以外では鉄道の利用頻度が減少しており、居住 者が自動車利用を前提とした転居を行っているため、 公共交通がますます利用されなくなっていることが 推察される。

7)「転居予定」の回答割合に着目すると、住宅地タイ プCL34、CL6、CL8、CL13、CL15のような都心周 辺部から郊外部に位置しており自動車利用頻度が増 加している住宅地タイプでは「転居予定あり」と答 えた人の割合が非常に小さいことが分かる。このこ とから、都心周辺部から郊外部の住宅地タイプでは 自動車依存度が高まっている上にその住宅地に住み 続けたいと考える定住志向の人が非常に多いことが 読み取れる。

8）住宅地タイプCL37、CL24のような都心部の住宅地 タイプでは逆に「転居予定あり」と答えた人の割合 が大きく、また先述のようにどちらも自動車利用頻 度が増加していることから、自動車に依存した生活 を保持しながらその利用に便利な郊外部に転居した 

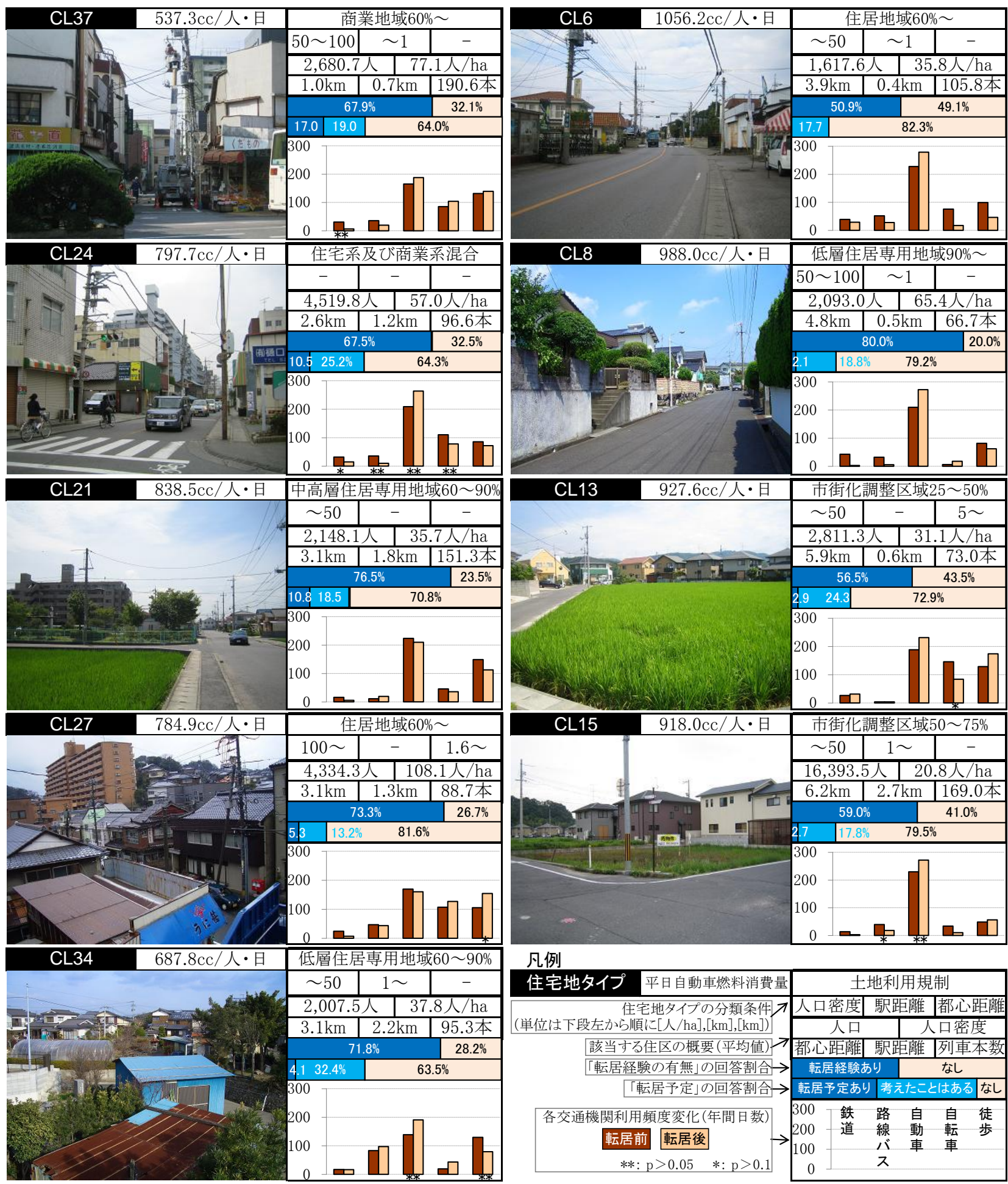

図ー1 住宅地タイプの概要と転居意向及び転居前後の各交通機関利用頻度変化

いと考えていることが推察される。

9) 自動車利用頻度が減少した住宅地タイプに着目する と、住宅地タイプCL21では「転居予定あり」と答え た人の割合が高く、中高層住居専用地域の割合が高 いことからも現在の居住地は仮住まいとして将来的 には転居を考えている人が多いことが推察される。 その一方で、住宅地タイプCL27では「転居予定あ り」と答えた人の割合も「転居を考えたことはあ
る」と答えた人の割合も小さく、定住志向の人が多 いことが読み取れる。

10) 住宅地タイプCL27やCL37では自転車や徒歩の利用 頻度が増加していることが特徵的であり、いずれも 商業施設も立地できる用途地域であることから、歩 いて暮らせるまちに住むことを志向していることが 推察される。 


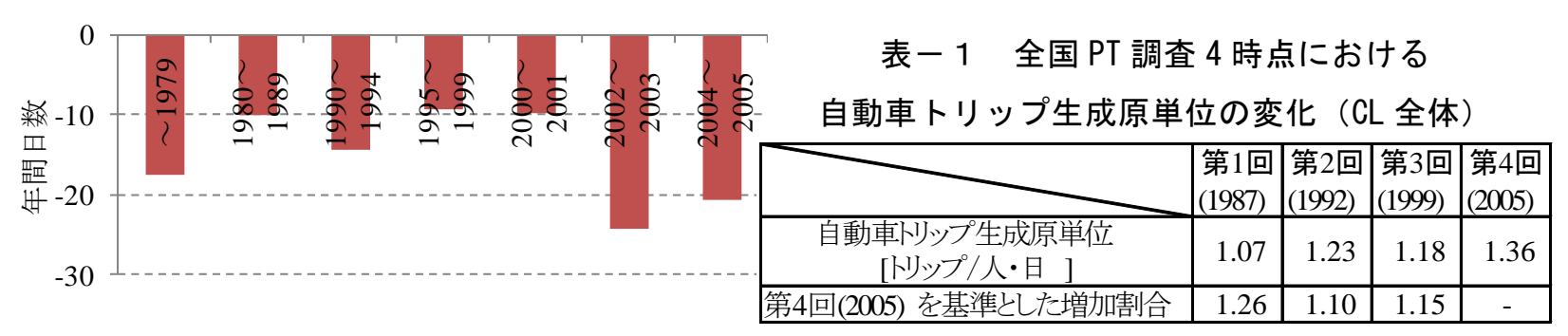

図-2 転居前後の鉄道利用頻度变化

（入居時期別 $\cdot C L$ 全体, $\mathrm{N}=1,650$ )

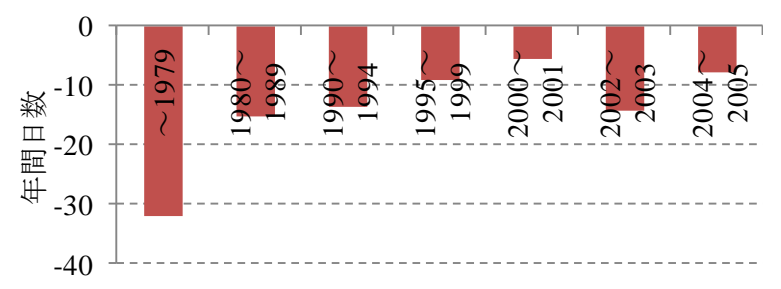

5. 入居時期別の自動車利用頻度变化分析

4. では入居時期に関係なく現居住地に移る際の転 居の全てを対象として分析を行ったが、ここでは過去に 転居してきた人が現在までに自動車利用頻度が変化して いることに配慮した考察が行えるよう、入居してきた時 期に着目して分析を行う。

まず、CLに該当するサンプル全体を対象に、各交通

図-3 転居前後のバス利用頻度変化

（入居時期別 $\cdot \mathrm{CL}$ 全体， $\mathrm{N}=1,650$ )

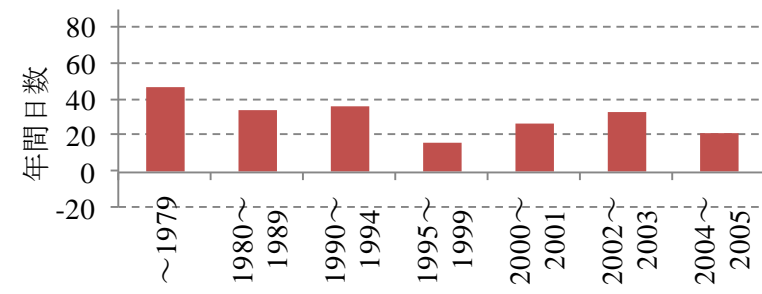

図-4 転居前後の自動車利用頻度変化

（入居時期別 $\cdot \mathrm{CL}$ 全体， $\mathrm{N}=1,650$ )

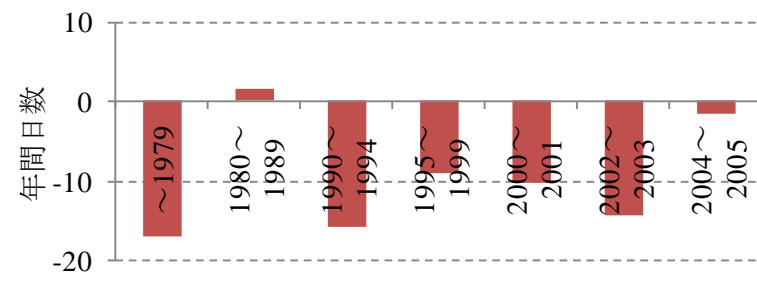

図－5転居前後の自転車利用頻度変化

(入居時期別 $\cdot C L$ 全体, $N=1,650$ )

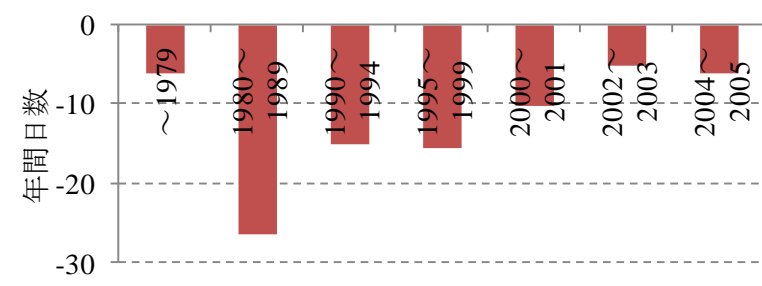

図－6 転居前後の徒歩利用頻度変化

（入居時期別 $\cdot \mathrm{CL}$ 全体， $\mathrm{N}=1,650$ )

機関の転居前後での利用頻度変化の平均值を算出した結 果を図一 2 図一 6 に示寸。入居時期については、現在 に近いほど転居してきたサンプル数が多くなるため、分 析にあたってサンプル数が十分確保できるよう7分割し ている。そして、過去の転居に関して現在までのCL全 体の自動車利用頻度の増加について把握するため、全国 PT調查が行われた4時点において自動車トリップ生成原 単位を算出したものを表一 1 に示す。これは 1 人 1 日あた りのトリップ数を示したものであり、図一 4 等に示した 1年あたりの日数とは直接的に比較はできないが、自動 車利用頻度の増加状況を比較するため、4時点のうちの 最新時点である2005年の自動車トリップ生成原単位の值 が過去3時点に対する増加率を示した。図ー2〜図ー6 を見ると、全体としては鉄道やバス、自転車、徒歩のよ うに自動車以外の交通機関については、一部を除く全て の入居時期区分において利用頻度がマイナスとなってお り、平均值としては自動車以外の交通機関の利用頻度は 転居前後で咸少していることが分かる。その一方で、C L全体で見ると自動車の利用頻度は入居時期によってほ とんど差がないが、1994年までに入居してきた人では相 対的に大きな值となっていることから、一見すれば、こ の頃に我が国全体で起きたモータリゼーションの急速な 進展により自動車利用頻度が大きくなっている傾向が現 われていると考えられる。しかし、表一 1 に示した2005 年を基準とした増加率の值と図一 4 の該当区分の值とを 比較すると、特に第1回(1987年)にあたる1980～1989年 の区分、第2回(1992年)にあたる1990～1994年の区分で は、表一 1 の割合以上に利用頻度が増加していることか ら、特に1994年までに入居してきた人では昔に行われた 転居であっても転居前後で自動車利用頻度が増加してい ることが読み取れる。

次に、都心側、郊外側で入居時期によっていつ頃か 


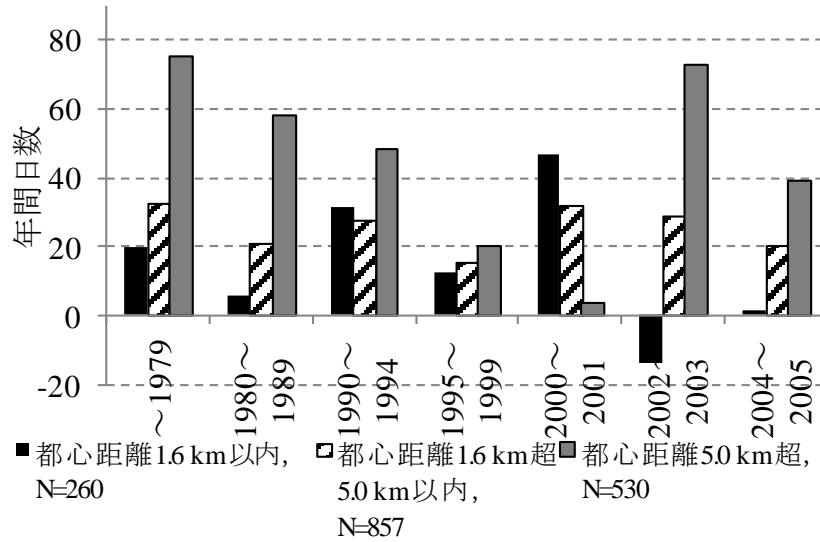

図-7 転居前後の入居時期 - 都心距離別 自動車利用頻度変化

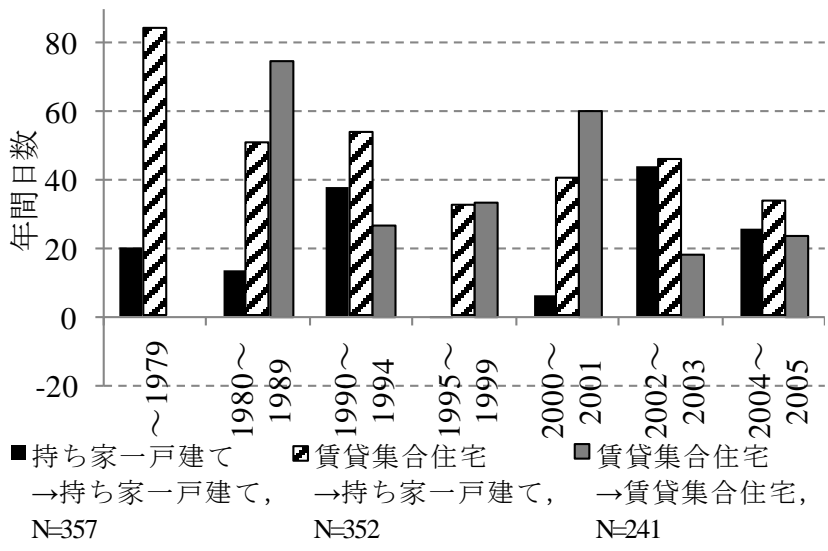

図－8 転居前後の入居時期 - 住宅の種類及び建て 方別自動車利用頻度変化

ら自動車利用頻度が増減しているか明らかにする。ここ では、住宅地タイプ別に分析するとサンプル数が少ない ため、都心距離によって大きく分類した。その分類区分 は住宅地タイプの分類条件に合わせ、都心部にあたる1. 6km以内、郊外部にあたる5.0km超、そしてその間の 1.6 $\mathrm{km}$ 超5.0km以内に分割しており、その区分ごとに自動車 利用頻度の変化のみを抜き出した分析結果を図一 7 に示 す。ここで、都心からの距離の区分については、住宅地 タイプ間で自動車燃料消費量が大きく異なるように配慮 して設定している24)。これを見ると、全体として入居時 期が古くなるほど自動車利用頻度の増加幅が大きくなる といった明確な傾向は見られなかったが、郊外部にあた る都心距離5.0km超の住宅地タイプにおいては、特に19 80～1994年に入居してきた人に関しては表－1 で示した 地方中心都市全体の自動車トリップ生成原単位の増加率 よりも自動車利用頻度の増加幅が大きいことから、我が 国全体の自動車依存度の増加による影響を除外しても転 居前後で自動車利用頻度が増していると読み取れる。ま た、これを他の都心距離5.0km以内の住宅地タイプと比 較すると、全体的に入居時期にほとんど関係なく自動車 利用頻度の増加幅が大きいことが分かる。それに対し都 心部と郊外部の間にあたる1.6km超5.0km以内の住宅地 タイプでは、入居時期に拘わらず自動車の利用頻度の増 加幅は郊外部ほど大きくない。ただ、本研究では紙数の 都合上示していないが1.6km超5.0km以内の住宅地タイ プでも鉄道やバスの利用頻度は増加しているわけではな くむしろ減少しているといら結果が得られており、転居 前後で顕著な交通行動の変化は見られないものの、傾向 としては自動車への依存度が高まっており、さらに郊外 部ではその傾向が強くなっているといえる。また、入居 時期で分割せずに分析した 4 。では都心部でも転居前後 で自動車利用頻度が増加寸る傾向が見られたが、都心部 にあたる1.6km以内の住宅地タイプでは近年入居してき

た人では自動車利用頻度はほとんど増えていないかむし ろ減少している傾向にあり、やはり郊外部での自動車依 存の抑制のほうが重要であることが分かる。

最後に、転居前後での住宅の種類及び住宅の建て方 によって分類して分析を行った結果を示すが、サンプル 数の多かった区分として、持ち家一戸建てから持ち家一 戸建てに転居してきたサンプルについて分析した結果、 賃貸集合住宅から持ち家一戸建てに転居してきたサンプ ルについて分析した結果、賃貸集合住宅から賃貸集合住 宅に転居してきたサンプルについて分析した結果につい て、それぞれ自動車利用頻度の変化を抜き出したものの みを図一8に示寸。また、個人属性と絡めた考察を行う ため、入居時の年齢別のサンプル数を集計したものを、 それぞれに対応させて図-9、図-10、図-1 1 に示 す。この結果、入居時年齢に着目すると、住宅の種類も 建て方も転居前後で同じものを選択している人の中でも、 賃貸集合住宅から賃貸集合住宅に転居してきた人々は若 年層に多いものの、持ち家一戸建てから持ち家一戸建て に転居してきた人々では分布が幅広い。これは、賃貸集 合住宅から賃貸集合住宅一転居してきた人が独身での就 職や結婚して間もない世代の転勤等が多い一方、持ち家 一戸建てから持ち家一戸建てへ転居した人については、 親と同居していた人が結婚後に 20 代、30代で一戸建てを 購入した場合と、その後の40代、50代でマイホームの建 て替えや相続により転居した場合の両方を含んでいるた めであると考えられる。その一方で、賃貸集合住宅から 持ち家一戸建てに転居してきた人々については、20代後 半から30代が多く分布幅が小さいことから、マイホーム 購入による転居を意味している場合がほとんどであると 考えられる。その一方で、賃貸集合住宅から持ち家一戸 建てに転居してきた人々については全体的に自動車利用 頻度の増加幅が大きく、特に1980～1994年に入居してき た人に関しては表一 1 で示した地方中心都市全体の自動 


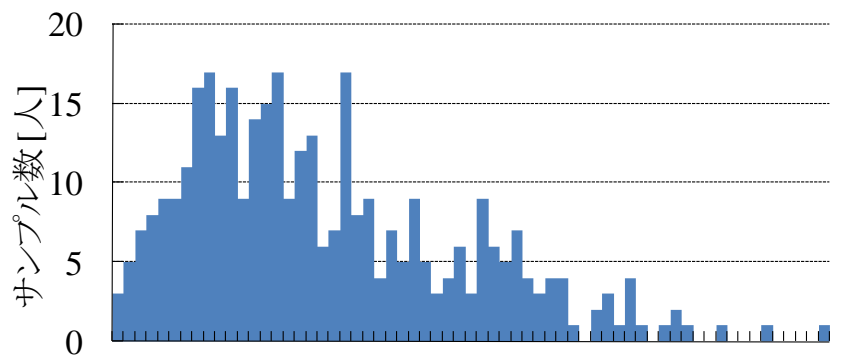

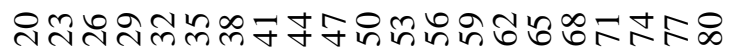
入居時年齢[歳]

図－9 入居時年齢別サンプル数

（持ち家一戸建て $\rightarrow$ 持ち家一戸建て， N=357）

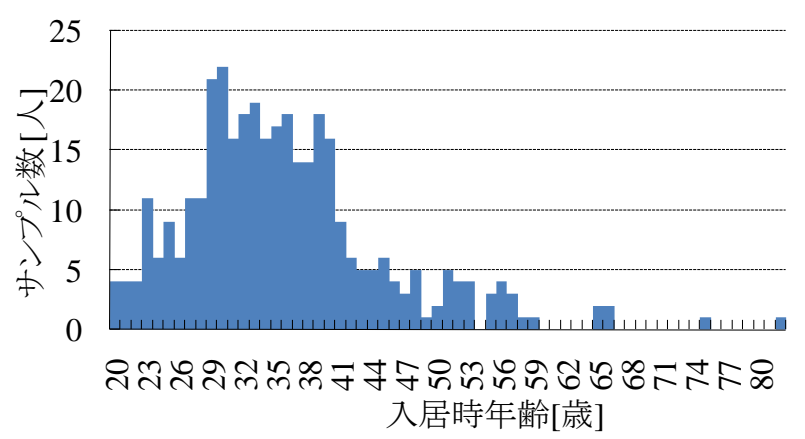

図-10 入居時年齢別サンプル数

（賃貸集合住宅 $\rightarrow$ 持ち家一戸建て，N=352）

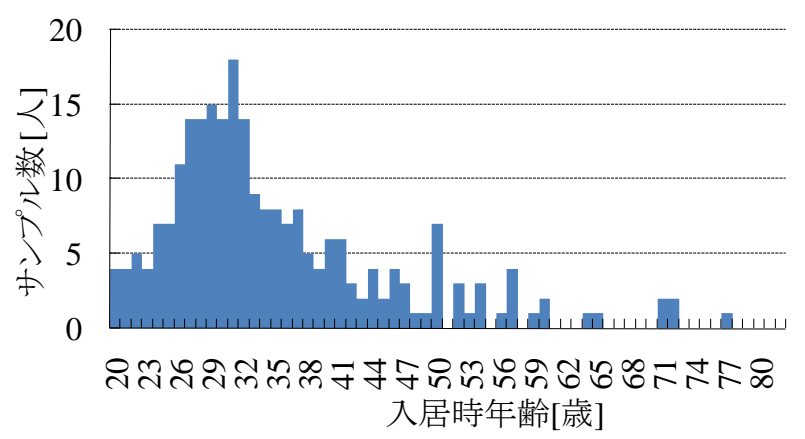

\section{図ー11 入居時年齢別サンプル数 \\ （賃貸集合住宅 $\rightarrow$ 賃貸集合住宅， $\mathrm{N}=241$ )}

車トリップ生成原単位の増加率よりも自動車利用頻度の 増加幅が大きいことから、我が国全体の自動車依存度の 増加による影響を除外しても転居前後で自動車利用頻度 が増していると考えられる。しかし、近年になって転居 してきた人では自動車利用頻度の増加幅が収まってきて いるというような明確な傾向も見られず、自動車に非常 に依存した生活にシフトしている人が多くなっているこ とが推察される。

\section{6. おわりに}

本研究では、大都市圏の都市を対象に全国規模のデー タを用いて、転居に伴う交通行動変化と転居意向の関係
を汎用性のある住宅地タイプ別に分析した。分析の結果、 住宅地タイプ、入居時期、住宅の種類及び建て方が全て 交通行動に影響していることが検証できた。

全体として、地方中心都市では自動車利用頻度が増加 した住区数が9割以上を占め、自動車利用頻度が減少し た住区よりも圧倒的に多いことが分かった。そして市街 化調整区域割合が高く都心からの距離も遠い郊外部の住 宅地タイプで自動車利用頻度の増加が見られる一方、都 心周辺部から郊外部に位置する住宅地タイプでも、低層 住居専用地域割合や住居地域割合が高く人口密度が小さ い住宅地タイプでは、自動車利用頻度の増加が見られた。 さらに、大都市圈では中心都市の都心部においては転居 前後で自動車利用頻度が減少する傾向も見られた 本研究で分析対象とした地方中心都市では、商業地域割 合が高い住宅地タイプや住宅系と商業系の用途地域を混 合させた住宅地タイプのような、いわゆる都心の商業地 区にあたる住宅地タイプでも、自動車利用頻度の増加が 見られた。このことから、具体的な住宅地タイプを取り 上げてみると、地方中心都市では郊外部だけでなく都心 部でも自動車依存の傾向が高まっていることが明らかに なった。また、このうち郊外部の住宅地タイプでは定住 志向の人が多い一方、都心部の住宅地タイプでは転居を 予定している人の割合が大きく、地方中心都市の都心部 では自動車依存度が高まっているだけでなくそこに住み 続けたいと考えている人は少ないことが分かった。

一方で、中高層住居専用地域割合の高い住宅地タイプ や人口密度が高い住居地域では、ごく少数ではあるが転 居前後で自動車利用頻度が減少していることが分かった。 ただし、マンションやアパートに居住している人は自動 車利用頻度が減少しているもののそこに住夕続けたいと 考えている人は少なく、住居地域のように商業施設も立 地した利便性の高い住宅地タイプへの居住を進めること で自動車利用頻度が減少しかつ定住志向の人を定着させ られる可能性があることが推察される。

ただし、全体として、本研究では、郊外部で自動車依 存度が増しているだけでなく、都心に近く商業施設や公 共交通が整備されておりこれまで一般的に自動車に頼ら なくても生活できると考えられてきた地区においても転 入者の自動車依存は従前居住地より高まっているケース が多いことが明らかとなり、政策の実効性を考える上で 重要な情報を整理することができたといえる。

また、入居時期に着目してさらに詳細に分析を行った 結果、まず、都心からの距離が1.6km以内の都心部全体 では、平均值で見ると特に近年は自動車利用頻度がほと んど増加していないという結果が得られた。前述の内容 も踏まえると、商業施設や公共交通が整備されている地 区では近年では自動車依存の傾向が収まってきていると いえる。さらに、都心から $1.6 \mathrm{~km}$ 超5.0km以内の都心周 
辺部では、入居時期に関係なく目立った増加傾向にはな いことが分かった。その一方で、都心から5.0km超の郊 外部に関しては自動車利用頻度の増加が目立ち、さらに 近年でもその増加が収まるというような傾向は見られな かった。また、20代後半から30代の世代に多い賃貸集合 住宅から持ち家一戸建てに転居してきた人々では、転居 前後で自動車利用頻度が増加しておりその増加幅は近年 でも大きい。都市コンパクト化を実現するためには転居 の果たす役割は重要であり、さらに転居はそれまでの交 通行動を見直し自動車に依存した生活を改善するには大 きなきっかけになると考えられる。しかし、これらの分 析結果から、地方中心都市では通年で見れば都心部でも 自動車依存の傾向は強まっているものの近年ではむしろ その増加が収まってきている傾向も見られた。これには 住宅の種類及び建て方と関連させた分析から得られたよ うに賃貸集合住宅から賃貸集合住宅への転居のように近 年の都心部でのマンション建設による自動車依存低減効 果が現れていることも推察できる。そのため、このよう な都心部への転居希望者よりも、郊外部の転居先を検討 しており、特に20代後半から30代でマイホーム購入を考 えている人々に着目し、そのような人々に対して重点的 に自動車依存の傾向を抑える努力が必要であるといえる。 ただ、それに対して都心部への転居者は、都心周辺部や 郊外部の転居者に比べて定住志向の人が少ないという結 果も得られており、今後は都心部での居住利便性を向上 させその魅力を高めることで、転入者の定着を進めるこ とが重要である。

一方で、居住者の具体的な二ーズとしては自動車に依 存した郊外部での生活を志向している人が多いと考えら れ、実際にこのまま転居が進めば実は拡散市街地が形成 される可能性が高いという予測結果も既に得られている 25)ため、単純に転居が促進されればいいとはいえない。 今後は、現在の居住者のニーズも詳細に踏まえた上で、 そのニーズをある程度反映させても交通環境負荷低減の 効果は望めるのか、それとも居住者のニーズ自体を変化 させる施策が必要なのか、あるいはニーズはそのまま考 慮しても交通行動を変化させる働きかけが重要なのか といったことをシナリオ分析等を通して明らかにしてい く必要がある。また、分析の結果、特に郊外部に転居し てきた人は自動車利用を前提に転居してきていることが 推測されるため、今後はさらに自動車の保有状況等の世 帯属性と絡めた分析を行っていくことが考えられる。さ らに、住宅地タイプ自体の変化についても考慮していく 必要がある。

最後になったが、本研究では国土交通省都市交通調査 室が実施した全国都市パーソントリップ調査データ活用 の機会を得た。記して謝意を表す。

\section{参考文献}

1)たとえば, Newman, P. and Kenworthy, J. : Cities and automobile dependence, a sourcebook, Hampshire, Gower Technical, 1989.

2)国土交通省都市・地域整備局 : 集約型都市構造の実現 に向けて一都市交通施策と市街地整備施策の戦略的 展開一，2007.

3)高橋美保子・出口敦 : コンパクトシティ形成効果の費 用便益評価システムに関する研究，都市計画学会論 文集，No.42-3，pp.487-492， 2007.

4)加知範康 ・ 岑貴志・加藤博和・大島茂・林良嗣 : ポテ ンシャル型アクセシビリティに基づく交通利便性評 価指標群とその地方都市への適用，土木計画学研 究・論文集，No.23，no.3，pp.675-686， 2006.

5)海道清信 : コンパクトシティの計画とデザイン，学芸 出版社, 2007.

6)谷口守: 都市コンパクト化と住宅需要マネジメントー 住宅不動産市場の動向をふまえて一，日本不動産学 会誌, Vol.15, No.3, pp.33-38, 2001.

7)古澤浩司・杉木直・青島縮次郎 : 地方都市におけるコ ンパクトシティ実現のための居住誘導施策とその効 果に関する分析，土木計画研究・講演集，No.25, CD-Rom, 2002.

8)㐘地吉信・野嶋慎二 : 地方都市における民間分譲住宅 地の開発実態と居住者移動に関する研究，都市計画 論文集，No.38-3，pp.61-66， 2003.

9)高木一成・森本章倫・古池弘隆 : 交通施設整備が住宅 立地行動に与える影響に関する実証分析，土木計画 学研究論文集, Vol.21, pp.197-202, 2004.

10)青木俊明・白井宏和 : 住居形態の選択行動からみた 今後の都市構造の変化, 土木計画研究 - 講演集,

No.34, CD-Rom, 2006.

11)香川貴志 : 中心市街地立地型の分譲マンション居住 者の前住地と通勤事情一札幌市中央区・岡山市・那 覇市を事例としてー，日本地理学会秋季大会シンポ ジウム, 2007.

12)大門創：人口減少下における地方中核都市の TOD 戦 略に関する研究，宇都宮大学大学院学位論文，2008.

13)高塚創・泉英明 : 郊外居住者の抱くまちなかイメー ジとまちなか居住意向：高松における実態調査から， 日本都市計画学会中学四国支部 都市計画研究公演集 6, pp.25-28, 2008.

14)Patricia L. Mokhtarian and Xinyu Cao : "Examing the impacts of residential Self-selection on travel behavior: A focus on methodologies," Forthcoming, Transportation Research Pt. B, 2008.

15)川野正史・谷下雅義 : 人口密度が自動車保有選択・ 走行量に与える影響分析，都市計画論文集，No.43-3， pp.841-846, 2008.

16)Petter Næss : Residential location affects travel behavior, but how and why? The case of Copenhagen Metropolitan 
Area., Progress in Planning, Vol. 63, No 2, pp.167-257, 2005.

17)Bhat C.R., Guo J.Y. : A comprehensive analysis of built environment characteristics on household residential choice and auto ownership levels., Transportation Research Part B 85th Annual Meeting Compendium of Papers CD-ROM ( HTML), 2006.

18)伊勢昇・日野泰雄・村上睦夫 ・田和裕 : 郊外住宅団 地における時間経過に伴う居住者属性と移動ニーズ の変化に関する研究, 土木計画学研究・講演集, No.36, CD-Rom, 2007.

19)島岡明生・谷口守・松中亮治：コンパクトシティ・ マネジメントにおける行動変容戦略の不可欠性，土 木学会論文集, No.786, IV-67, pp.135-144, 2005.

20)中道久美子・島岡明生・谷口守・松中亮治 : サステ イナビリティ実現のための自動車依存特性に関する 研究，都市計画論文集，No.40-3，pp.37-42， 2005.
21)中道久美子・谷口守・松中亮治 : 転居を通じた都市 コンパクト化による自動車依存低減の可能性 -大都市 圈における転居前後の交通行動変化分析を通じて-, 都市計画論文集，Vol.43-3，pp.889-894， 2008.

22)藤井聡・染谷祐輔 : 交通行動と居住地選択行動の相 互依存関係に関する行動的分析, 土木計画学研究 論文集，Vol.24(3)，pp.481-488，2007.

23)藤井聡 : 交通行動が居住地選択に及ぼす影響につい ての仮説検証 : コンパクト・シティの誘導に向けた 交通政策に関寸る基礎的研究, 交通工学, Vol.43, No.6, pp.53-62, 2008.

24)谷口守・松中亮治・中道久美子 : ありふれたまちか ど図鑑一住宅地から考えるコンパクトなまちづくり 一，技報堂出版株式会社，2007.

25)村川威臣・谷口守・中野敦 : 居住ニーズからみた住 区整備による交通環境改善策の実現可能性，都市計 画論文集，No.35，pp.337-342，2000.

\section{地方中心都市における転居を通じた都市コンパクト化による自動車依存低減の可能性*}

近年、コンパクトシティが推進されているが、交通環境負荷低減のためには転居とともにその前後で居住者 の交通行動が変化し自動車依存状況が改善される必要がある。そこで本研究では、幅広い住宅地を含む地方中 心都市を対象に全国規模のデータを用いて転居前後の交通行動の変化についてその実態を地区属性別に明らか にすることを目的とする。さらに、転居してきた時期や、都心からの距離、住宅の種類や建て方の変化につい ても把握しながら分析を行うことで、郊外から撤退し交通等のインフラの整った都心あるいは駅周辺部に人口 を誘導するようなコンパクトシティの推進によって、交通環境負荷を低減させる可能性があるか考察を行った。

The Possibility for Reduction of Car Dependence from the Perspective of Relocation for Compact City in Central City of Local City*

By Kumiko NAKAMICHI** • Mamoru TANIGUCHI*** $\cdot$ Ryoji MATSUNAKA****

Though several municipalities have already promoted compact city, the resident's car dependence lifestyle should improve with the relocation in order to decrese environmental load. This study is intended to clarify the change of travel behavior before and after relocation along with each residential zone characteristics of central city in local area, using the nationwide data. Moreover, this study also argues that the car dependence situation can change and environmental load can be decreased in reality by promoting compact urban layout by analysis considered with relocation time, distance to the city center and the change of the kind of house.. 